\title{
DISCOVERY OF MAIZE PRICE AND FOOD CROP MARKET DYNAMICS IN NIGERIA
}

\author{
Toyin Benedict AJIBADE *1 (D), Opeyemi Eyitayo AYINDE ${ }^{1}$ (iD), Tahirou ABDOULAYE ${ }^{2}$ (iD)
}

\author{
Address: \\ ${ }^{1}$ University of Ilorin, Faculty of Agriculture, Department of Agricultural Economics and Farm Management. PMB \\ 1515, Ilorin, Nigeria. \\ ${ }^{2}$ International Institute for Tropical Agriculture, PMB 5320, Oyo Road, Ibadan, Nigeria. \\ * Corresponding author: ajibade.tb@unilorin.edu.ng
}

\begin{abstract}
Having the mandate of achieving food security in Nigeria, commendable efforts have been geared towards food production in the nation. Albeit the increasing production, price volatility has continued to perpetuate in food markets in Nigeria hence attaining food affordability, a precondition for food security, remains a mirage. An innovative approach to the food challenge therefore, may be to understand the food markets dynamics such as to gain insight into how the market works. In this study we focus on maize, a very important staple in Nigeria. We seek to identify the point of price discovery and markets that significantly influence price of maize. In furtherance, we examine the dynamic relationship existing among the markets and explored the responsiveness of the markets to price signals from the other markets. Our results showed that most of the markets examined behave in such a manner expected of open market however full market integration has not been achieved. It was revealed that prices of maize are discovered from major food market in the deficit production zone. Majority of the markets were responsive to one-time price shock from itself, although exhibiting exogeneity in the contemporaneous period but becoming endogenous by the long run (whereby other markets majorly influenced prices) hence indicating that the markets had commendable informational influence on one another. The study therefore recommended installing infrastructure for linkage of production with the demand zones if price stabilization is to be achieved. Regulatory bodies should also check activities of cartels in the influential markets.
\end{abstract}

Keywords: Agricultural Markets, Food crop, Impulse response function, Nigeria, Price discovery, Variance decomposition

JEL: L1, Q11, Q13

\section{INTRODUCTION}

With rising population, the challenge of how to feed the additional mouths has continued to stare nations in the face given the recognition that food security remains a key component of stability in any economy. Over the years, food security has drawn so much attention globally and in fact, at the World Food Summit of 1996, governments reaffirmed the right to food and committed to halving the number of hungry and malnourished from 840million to 420million in 2015. Statistics has shown the world has failed horrendously to achieve this objective seeing that the hungry has grown in excess of 1billion globally as at 2012 (Conway, Wilson and Shah,2012) The Right to Food, derived from the International Covenant on Economic, Social and Cultural Rights (of the United Nations Treaty Collection) in May 2012 saw many States signing a covenant to direct efforts at taking steps to the maximum of their available resources to achieve progressively the full realization of the right to adequate food both nationally and Internationally. Although, empirical evidence suggests that Africa is one of the continents with the biggest food problems globally, it cannot be concluded that the continent is one that has geared inadequate efforts towards solving her food crisis. Nigeria, the most populous nation in Africa has over the years come up with various strategies and programmes directed at curtailing food price volatility and invariably the attainment of food security.

Based on a study by Olomola (2015), these may be classified as short, medium and long-term measures. The short-term measures involve release of grains from the National reserves in order to crash the prevailing prices; mopping up operations entailing the buying of food stock from local stores followed by sales of these foods to consumers at subsidized rates; distribution of small-scale machines targeted at assisting the local farmer/producers and also the waiver of tariffs to stimulate private sector into food imports such as to raise supply and lower market prices eventually. Medium terms measures were as well taken and some of these involve the allocation of 1.68 percent of the federal budget to the Natural Resources Development Fund during 2008-11 for boosting the domestic production of food crops, the development of the agro-allied industry, and research and development (RandD) on seed varieties; provision of agricultural funds 
as a credit scheme at a concessionary interest rate; completion of all outstanding National Food Reserve storage facilities; while the long term measures were harness in the nation's food security strategy document which has policy thrust along the line of value chain approach to agricultural development, commodity focus in providing support to producers, successor farmer generation, provision of safety nets for producers.

These efforts are logically appealing, to the benefit of Africa as a whole because an imminent food crisis in Nigeria, with the size of its population, will be a regional disaster for neighbouring African countries if they have to be a source of relief and asylum to that effect. Various agricultural indices have shown the evolvement of food production in Nigeria, supported in expansion of hectarage, higher yields and of course increasing production. Albeit, food prices in Nigeria has continued to be volatile which is a constraint to food affordability and invariably food security in the nation. Most of the policy measures and approaches taken towards stabilizing food prices have proven to be unsustainable. According to Díaz-Bonilla (2016), this is mostly caused by fiscal costs, the distortions generated in production and trade when not using market prices, and the usually inequitable distribution of costs and benefits.

Tsimpo and Wodon (2008) linked the constantly rising price of staples in developing countries to low domestic production, seasonal production variability, high transaction cost, inefficient markets and a high reliance on imports. Olomola (2015) ascribe the escalating food prices in Nigeria to demand pressures from neighbouring countries some of which have experienced food riots, substitution effect of the 2008 food crisis and the high cost of transportation in due to rising cost of petrol being imported. Nigeria is among many African countries that have engaged in agricultural liberalization since 1986 in the hope that reforms emphasizing price incentives will encourage producers to respond. Hitherto, the reforms seem to have introduced greater uncertainty into the market given increasing rates of price volatility (Ajetomobi, 2010). Being characterized by the dominance of resource-poor individuals not only in the production but also in the marketing arm of agriculture, the volatility in pricing of agricultural commodities has far reaching implications for majority of the players in the industry.

One innovative way to approach the food challenge, therefore, may be to understand the market having established that increased production as a strategy has failed to be the magic wand in enhancing food access. Gaining insight into the nuances, operationality and dynamics in food crop markets in Nigeria becomes pertinent. In this study, we lay emphasis on the grain subsector given its importance (Awoyemi et al., 1986; Balami, Ogboru and Talba, 2011; Bio, Dahuri and Roger, 2015) and we focus on Maize which is justified by the fact that it is one of the most common staples and one mostly traded in Nigeria, likewise having multiplicity of use as food, in agribusinesses, brewery, pharmaceuticals, exportation, bio-fuels and consequently, with capacity to indirectly impact on the employment level in the nation (Ihimodu, 2007; Matthew and Ben, 2016;
Mansharamani, 2012; Maziya-Dixon, Akinyele, Oguntona, Nokoe, Sanusi and Harris, 2004). To reconnoitre the Nigerian domestic grain markets, this study was designed to: identify the point of price discovery and markets that significantly influence price of maize; examine the dynamic relationship existing among the markets; and explore the responsiveness of the markets to price signals of maize in the other markets. Gaining insight into price and market dynamics will be smoothening out the existing information asymmetry hence better positioning market players towards more galvanized and sustainable food markets system in Nigeria. The study was carried out in Nigeria, a country consisting of 36 states and the Federal Capital Territory, Abuja. Located in West Africa on the Gulf of Guinea, Nigeria has a total area of $923,768 \mathrm{~km} 2(356,669$ sq. mi). Nigeria, Africa's most populous country is one of the ten most populous countries in the world. The population is growing rapidly, rising from 88.9 million in 1991 to 140 million in 2006 and 193.4 million in 2017 (NPC, 2017) and about $70 \%$ of the population are engaged in agricultural production albeit at subsistent levels (World Bank, 2015).

\section{DATA AND METHODS}

\section{Data description and Sampling Procedure}

Panel data for this study include prices of the selected food crop, maize, which were primarily sourced over a period of 52 weeks from 24 markets across 11 states and the FCT in Nigeria between September 2015 and August 2016. Modal prices of maize were collected in each of the selected market on a weekly basis through market enumerators and these were cross-verified from traders and buyers in the marketplace in order to authenticate the veracity of the collected data. For the purpose of monitoring the enumerators, spot checks were made as unscheduled visits to various market locations during the course of the study. Contacts were also established with various traders at the initial visitation to all the selected states during sampling of traders and random calls to them which further served as a means of ensuring reliability of the weekly price data being collected by enumerators. A four-stage sampling procedure was engaged to select the 24 markets earlier stated. Stage one involved the stratification of the states in Nigeria based on the agroecological zones. States that overlapped in terms of multiple agro-ecological zones were pooled together and eventually there were two strata. The first stratum includes Mangrove/Fresh water swamp/Rainforest zones while the second stratum includes Short grass guinea savanna/Marginal savanna woodland/Tall grass savanna zones. The second stage involved the random and proportionate selection of $30 \%$ of the States in each stratum. Four States were selected from the first stratum while seven States were selected from the second stratum to give a total number of eleven (11) states. This was done with a level of approximation. The Federal Capital Territory was purposively selected alongside the eleven states to give total of twelve (12) locations. The third stage involved both purposive selection of the major food crop market in the state capital and random selection of one 
rural food crop market from each of the twelve (12) selected locations. Information on the market listing was sourced from The States' Ministry of Commerce and Trade.

\section{Theoretical framework}

In this study, we theorize that food crop markets being investigated may be seen as the individual level whereas it is expected that some form of interrelationships exists amongst the various food markets in the economy on the overall which tends to bunch and determine how the prices flow. Firstly, we define market as a system, institutions, procedures, social relations and infrastructures whereby parties engage in exchange and this is the process by which the prices of goods and services are established. While parties may exchange goods and services by barter, most markets rely on sellers offering their goods or services (including labour) in exchange for money from buyers. Markets facilitate trade, enable the distribution and allocation of resources in a society while also allowing any trade-able item to be evaluated and priced.

As explained explicitly by Kirzner (1963), a market exists whenever the individual members of a society are in sufficiently close contact to one another to be aware of numerous such opportunities for exchange and, in addition, are free to take advantage of them. Furthermore, a market economy exists wherever the ramifications of the market become so widespread and the opportunities it offers so numerous and attractive that most individuals find it advantageous to carry on their economic activities predominantly through the market rather than on their own. The market economy is thus to be distinguished, on the one hand, from the autarkic economy, where individuals carry on their economic activity isolated from one another, being unaware or unwilling to take advantage of opportunities for exchange. On the other hand, it is to be distinguished from the centrally controlled economy where economic activity of individuals is directed by a central authority so that, although transfers of goods among individuals may be ordered by the central authority, individuals are not free to take advantage of exchange opportunities which they themselves may perceive.

All actions connected to the notion of the market can be traced back to one single type of action which is exchange. In other words, this may be regarded as the buying and selling goods and services. Exchange is voluntary and mutually beneficial or else it would not take place (Buchanan and Tullock 1965). Gauthier (1986) stated that the market nexus is free from violence in a narrow sense and at least by tendency, also free from all considerations of solidarity. Market participants are neither enemies nor friends. Systematically, the market players regard each other just with regard to their abilities and skills, in their capacity to deliver something regarded as useful therefore, they regard each other just as a link in the chain (Wicksteed 1933). According to Thielmann (2000), in market exchange, as far as it is motivated solely by considerations of efficiency and advantage, participants treat each other as means. The other is able, having the power to contribute efficiently, or else will be excluded. Therefore, market exchange, as such, is not constituted by inter-subjectively sharable meanings or reasons.

During any given period, therefore, the decisions made by individual market participants constitute an interlocking system embracing the entire scope of the market. This network of decisions constitutes the market system. The end results of all these decisions make up the achievements of the market system; and the tasks which society may seek to fulfil by permitting a market economy are the assigned functions of the market system (Kirzner, 1963). The expectation of economists and market participants from the activities that go on in the market is such that the markets can be said to be efficient. Such efficiency is tied to how well the markets are integrated and how fast information on the commodity pricing are able to get transmitted and circulated within and among markets. It is expected that if transportation costs and economic barriers are taken off from markets, each commodity should have a uniform price that cuts across all the markets. This phenomenon is referred to as the Law of One Price which is an economic theory positing that a good must sell for the same price in all locations. This law is derived from the assumption of the inevitable elimination of all arbitrage (Góes and Matheson, 2015; Mankiw 2011). The law of one price is otherwise known as the Fundamental law of one price identity (FLOPI). Assuming $P^{L}$ and $P^{C}$ denote the prices of a food crop in Markets $\mathrm{L}$ and $\mathrm{C}$ respectively with the corresponding transport and transactions costs to taking the food crop from market $\mathrm{C}$ to $\mathrm{L}$ is $P^{T} C$. Then the law of one price adjusted for transport and transaction costs implies the equilibrium known as the law of one price which is stated as Equation 1.

$P^{L}=P^{C}+P^{T} C \Leftrightarrow \frac{P^{L}}{P^{C}+P^{T} C}=1$

In case the two markets both produce and can trade a commodity in either direction the law of one price states that the price difference should be smaller or equal to transport and transaction costs. FLOPI then is smaller or equal to one. If the price difference is larger than transport and transaction costs, trade will close the gap. There are possibilities that the local demand and supply conditions in two markets may be such that price differences are smaller than transport and transaction costs and there will not be any need for trade in which case both markets are somewhat self-sufficient (Persson, 2008).

According to Fan and Wei (2005), the law of one price implies that the prices for the same product sold in different markets tend to converge to the same level due to profit incentives and market forces. In mathematical terms, the convergence to the law of one price for a product means that the time series of its relative prices is mean-reverting or stationary. Moreover, there may be significant costs of transportation and transaction in interregional trade, which complicates the dynamics of price convergence. Indeed, the issues of market integration and the law of one price are central to the very foundation of the discipline of economic.

The intuition behind the law of one price is based on the assumption that differences between prices are 
eliminated by market participants taking advantage of arbitrage opportunities (Persson, 2008). Assume different prices for a single identical good in two locations, no transport costs and no economic barriers between both locations. The arbitrage mechanism can be performed by both the supply and/or the demand site: All sellers have an incentive to sell their goods in the higher-priced location, driving up supply in that location and reducing supply in the lower-priced location. If demand remains constant, the higher supply will force prices to decrease in the higherpriced location, while the lowered supply in the alternative location will drive up prices there.

Conversely, if all consumers move to the lower-priced location in order to buy the good at the lower price, demand will increase in the lower-priced location, and assuming constant supply in both locations - prices will increase, whereas the decreased demand in the higherpriced location leads the prices to decrease there (Persson, 2008). Either of the scenarios mentioned will result in a single, equal price per homogeneous commodity in all locations (Lamont and Thaler, 2003). The law of one price also defines the extent of the market and measures market integration (Stigler and Sherwin, 1985). If a single price exists over several spatially separate markets, it implies that these markets are integrated as a single market. Measurement of market integration can be viewed as basic to understanding how specific markets work (Ravallion, 1986).

According to Persson (2008), perfectly efficient set of markets will allow only very short violations of the law of one price however, this is too strong a condition to be of practical significance. There are always local shocks which will take time to get diffused to other markets and distortions of information will make global shocks affect local markets differently. How long violations can persist depends on the state of information technology, whether markets operate with inventories and how competitive markets are. In furtherance to this, it was also stated that convenient econometric way of analysing the nature of the law of one price as an "attractor equilibrium" is an innovation correction model of the error terms which is meant to estimate an equilibrium law of one price. If markets are not well integrated one cannot establish or estimate FLOPI. Given the existence of a long-run or equilibrium price relationship between markets, a violation is known as "innovation" or shock, which will be corrected for so that the equilibrium price difference is restored. The innovation correction model is usually expressed in differences of $\log$ prices and the error correction model in this case may be stated as Equation 2.

$\Delta P_{t}^{L}=\alpha^{L} \ln \left(\frac{P_{t-1}^{L}}{P_{t-1}^{C}+P_{t-1}^{T C}}\right)+\varepsilon_{t}^{L}$
$\Delta P_{t}^{C}=\alpha^{C} \ln \left(\frac{P_{t-1}^{L}}{P_{t-1}^{C}+P_{t-1}^{T C}}\right)+\varepsilon_{t}^{C}$

The price shocks or innovation is mostly shown in an innovation correlation matrix and usually, the magnitudes of the parameters are an indicator of the efficiency of the markets. The higher they are, the faster will the equilibrium law of one price (FLOPI) be restored and the more efficient the markets being investigated are. Cointegration is one of the tests for law of one price and this was as employed in this study in order to establish the integration of the Nigerian agricultural markets modelled.

\section{Model Specification}

Our model follows the work of Vitale and Bessler (2006), in which case we seek to identify the points of price discovery and markets that significantly influence prices of maize. This analysis was approached through a (cointegrated) Vector Auto Regression model in which Directed Acyclic Graphs (DAGs) are used to sort out causal flows of price information in contemporaneous time.

Based on apriori knowledge that prices in a free market are non-stationary and which has been established on the series worked on. Then let, $\mathrm{X}_{\mathrm{t}}$ denote a vector which includes the weekly prices ( 52 observations) from each of the 24 markets that were sampled, and this vector can be modelled in an error correction model stated as Equation 3.

$\Delta X_{t}=\prod X_{t-1}+\sum_{i=1}^{K-1} \Gamma_{i} \Delta K_{t-i}+\mu+e_{t}$

Where, $t=1,2,3 \ldots \ldots T_{i}, E\left(e_{t} \mathrm{e}_{t}^{\prime}=\Omega\right.$ is positive finite, $\Pi$ and $\Gamma$ are parameter matrices to be estimated, $\mu$ constant, $\mathrm{e}_{t}$ white noise innovation term

Equation (3) is synonymous to a vector autoregression (VAR) model in first differences but for the presence of the lagged levels of $\mathrm{X}_{t-1}$. There are three possible outcomes in this estimation and each of these has various implications as follows:

1. If $\Pi$ is of full rank, then $X_{t}$ is stationary in levels and a VAR in levels is an appropriate model.

2. If $\Pi$ has zero rank, then it contains no long run information and the appropriate model will be a VAR in first difference.

3. If $\Pi$ has a rank of positive number $r$, which is less than $p$ (where $p=$ number of series i.e. 24 markets, then there exist matrices $\alpha$ and $\beta$, with dimensions $\mathrm{p}$ by $\mathrm{r}$, such that $\Pi=\alpha \beta^{1}$ in which case $\beta^{1} X_{t}$ is stationary even though $X_{t}$ is nonstationary.

From literature (Sims, 1980; Swanson and Granger, 1997 and Vitale and Bessler, 2006), the dynamic price relationships can best be summarized through the moving average representation. The estimated form of equation (3) may be algebraically expressed as a levels VAR from which point the moving average representation for it is solved. The $\mathrm{X}_{t}$ is written as a function of the infinite sum of past innovations (Eq.4).

$\mathrm{X}_{t}=\sum_{i=0}^{\infty} G_{\mathrm{i}} e_{t-1}$

Where $G_{\mathrm{i}}$ is a 24 by 24 matrix of moving average parameters which map historical innovations at lag $i$ into the current position of the vector X. According the Vitale and Bessler (2006) after whom this work is being modelled, the matrix $G_{0}$ is generally not the identity matrix as the elements of the vector $e$ are usually not orthogonal as there may be non-zero correlation between 
contemporaneous innovations hence analysis of Equation (4) without making some adjustment for non-orthogonal innovations may not reflect the dynamic historical patterns present in the data.

It is more desirable to work with a transformed moving average representation on orthogonalized innovations (Eq. 5).

$v_{t}=A_{e t}$

where, A is such that $E\left(v_{t} v_{t^{1}}\right)=D$ and $D$ is a diagonal matrix.

The next step in the procedure involves the application of directed acyclic graph algorithms to place zeros on the A matrix.

From the estimated form of equation (4), the vector X in terms of the orthogonalized innovations may be stated as Equation 6.

$X_{t}=\sum_{i=0}^{\infty} \Theta_{i} V_{t-i}$

(whereby the vector $\mathrm{X}$ is written as an infinite series of orthogonalized innovations, $V_{t-i}$ )

Graph theory and PC algorithm are then used to determine the causal pattern behind the correlation in contemporaneous innovations. A directed graph is a pictorial representation of the causal flow among variables. Usually, lines with arrowheads are used to represent flows such that $A \rightarrow B$ indicates that variable $A$ causes variable $B$. In a situation whereby the line connecting two variables for instance $E-F$, does not indicate any arrow direction, then it implies the two variables $E$ and $F$ are connected by information flow however there is no knowledge as related to causal relationship between the variables. According to Pearl (2000), the fundamental idea that allows us to detect direction of causal flow to a set of (observational) variables is that of screening-off phenomena and their more formal representations as d-separation. For three variables $A B$ and $C$, if we have variable $A$ as a common cause of $B$ and $C$ so that $B \leftarrow A \rightarrow C$, then the unconditional association between $B$ and $C$ will be nonzero, as both have a common cause in $A$ and this type of diagram is labelled a causal fork according to Pearl (2000).

Vitale and Bessler (2006), stated that if one measure association (linear association) by correlation then $B$ and $C$ will have a non-zero correlation. However, if one conditions on $A$, the partial correlation between $B$ and $C$ (given knowledge of $A$ ) will be zero as knowledge of the common cause $(A)$ "screens-off" association between its effects $(B$ and $C)$.

On the other hand, considering variables $D, E$ and $F$ such that $D \rightarrow E \leftarrow F$. It implies that $E$ is a common effect of $D$ and $F$ and this diagram is labeled a causal inverted fork (Pearl 2000). $D$ and $F$ will have no association (zero correlation if the relationship is constrained to linear association); however, if one conditions on $E$, the association between $D$ and $F$ is nonzero (the partial correlation between $D$ and $F$, given knowledge of $E$ is non-zero) and it can be said that knowledge of the common effect does not "screen-off" association between its causes (Vitale and Bessler, 2006). Vitale and Bessler (2006) stated further that in case of variables $G, H$ and $I$ forming a causal chain, $G \rightarrow H \rightarrow$ $I$, the unconditional association (correlation) between $G$ and $I$ will be non-zero, but the conditional (partial) correlation between $G$ and $I$, given knowledge of $G$ and $H$, will be zero. Spirtes, Glymour and Scheines (2000) and Pearl (2000) present algorithms with similar structures and outputs for inference on directed acyclic graphs from observational data.

In order to examine the dynamic relationship existing among the selected markets, the Impulse response function was applied to the fitted Vector Autoregressive model to enable one interpret and describe the reactions of dynamic system existing in each of the modelled market to external changes resulting from the other markets that parameterize the dynamic behaviour of the entire system. This exhibit result in the form of how price in each of the market responds to a one-time-only shock on every other sampled market price. Based on explanation by Rossi (2010), it may be stated that the impulse response function traces the effect of an exogenous shock or innovation in one of the markets on all the other markets modelled in this study and thereby supplying information of the types of causality that exist in the modelled markets.

The impulse response function can be stated as the Eq. 7.

$y_{t+n}=\sum_{i=0}^{\infty} \Psi_{i} \epsilon_{t+n-i}$

where., $\left\{\Psi_{n}\right\}_{\mathrm{i}, \mathrm{j}}=\frac{\partial y_{i t+n}}{\partial \epsilon_{j t}}$ with the response of $y_{i, t+n}$ to a one-time price shock or impulse in $y_{j, t}$ with all other markets dated $t$ or earlier held constant. The response of price in market $i$ to a one-time price shock in market $j$ is mostly depicted graphically to have a visual impression of the dynamic inter-relationships within the system whereas the percentages were as well generated in a tabular form.

According to Ronayne (2011), the Impulse response function is a powerful new analytical weapon offered by the VAR methodology. Impulse response functions are used to track the responses of a system's variables to impulse of the system's shocks. Ronayne (2011) stated that the standard Impulse response function uses estimation from the estimated VAR model. This methodology of generating of Impulse response functions involves non-linear (at horizon greater than one) functions of the estimated VAR parameters. Ronayne further stated that the order of the polynomial increases as the horizon shifts even higher. Given that the horizon is fixed at 1 , the VAR will produce the optimal one-step ahead forecast. Stock and Watson (1999) even stated that despite a misspecification of model, a VAR process will still produce reliable one-step ahead forecast.

The graphs indicate a broad pictorial representation which may easily be understood while the tabular form states the percentages associated with each of the graphs. The impulse responses are zero if price in one of the markets does not granger cause prices in the other markets in the modelled system whereas, an innovation in price in 
market $k$ has no effect on the prices in other markets. In other words, market $k$ price does not granger cause the set of remaining markets within the modelled system.

In exploring the responsiveness of each of the selected markets to price signals of Maize in the other markets, the Forecast Error Variance Decomposition was applied to partition the price uncertainties in each market at different time periods in order to reveal how each market responded to externalities in price signals. The Forecast error variance decomposition measured the contribution of each shock type to the Forecast error variance and determined the quantity of the Forecast error variance of each of the markets that could be explained by exogenous shocks to the other markets.

Lütkepohl (2007) stated that in econometrics and other applications of multivariate time series analysis, a variance decomposition or forecast error variance decomposition (FEVD) is used to aid in the interpretation of a vector autoregression (VAR) model once it has been fitted.

According to Zivot and Wang (2006), forecast error variance decomposition answers the question: what portion of the variance of the forecast error in predicting $y_{i, T+h}$ is due to the structural shock $\eta_{j}$

Using the orthogonal shocks $\eta_{t}$ the h-step ahead forecast error vector, with known VAR coefficients, may be expressed as Equation 8.

$Y_{T+h-} Y_{T+h \mid T}=\sum_{s=0}^{h-1} \Theta_{s} \eta_{T+h-s}$

Whereas, for a particular variable $y_{i, T+h}$, the forecast error is of the form indicated in Equation 9.

$y_{i, T+h}-y_{i, T+h \mid T}=\sum_{S=0}^{h-1} \Theta_{i 1 \eta 1, T+h-s}^{S}+\ldots+$
$\sum_{S=0}^{h-1} \Theta_{i n}^{S} \eta_{n, T+h-s}$

Since the structural errors are orthogonal, the variance of the h-step forecast error may be written as Equation 10 . $\operatorname{var}\left(y_{i, T+h}-y_{i, T+h \mid T}\right)=\sigma_{\eta 1}^{2} \sum_{s=0}^{h-1}\left(\Theta_{i 1}^{S}\right)^{2}+\cdots+$ $\sigma_{\eta n}^{2} \sum_{s=0}^{h-1}\left(\Theta_{i n}^{S}\right)^{2}$

Where $\sigma_{n j}^{2}=\operatorname{var} \eta_{j t}$. The portion of $\operatorname{var}\left(y_{i, T+h}-\right.$ $y_{i, T+h \mid T}$ ) due to shock $\eta_{j}$ is therefore stated in Equation 11.

$$
F E V D_{i, j}(h)=\frac{\sigma_{\eta j}^{2} \sum_{s=0}^{h-1}\left(\Theta_{i j}^{S}\right)^{2}}{\sigma_{\eta 1}^{2} \sum_{s=0}^{h-1}\left(\Theta_{i 1}^{S}\right)^{2}+\cdots+\sigma_{\eta n}^{2} \sum_{s=0}^{h-1}\left(\Theta_{i n}^{S}\right)^{2}}, i, j=
$$

Zivot and Wang (2006) further stated that Forecast error variance decomposition largely depends on the recursive causal ordering used to identify the structural shocks $\eta_{t}$ and is not unique therefore different causal orderings will produce different FEVD values.

Some underlining information in the report on Forecast Error Variance Decomposition in this study is the fact that a market may be regarded as being exogenous or endogenous at a point in time on the basis of how much proportion of the market's uncertainty is being explained by other markets being sampled alongside the market. In a situation whereby a large proportion of the forecast error decomposition is accounted for by other markets, then the market is taken to be an endogenous one which implies the market is a dependent market. However, when only a minimal proportion of the forecast error decomposition of that market is accounted for by other markets, then the market under scrutiny is taken to be an exogenous one, in other words such a market is independent.

Another important note to the tabular report given on the Forecast Error Variance Decomposition as well as the corresponding points on the graph is that there are ten variance periods indicated in the report with these representing the weeks under investigation. Variance period one indicates the contemporaneous time while variance periods two, five and ten signify the short run, intermediate run and the long run respectively. It is worthy to note that summation of all the observations across each of the variance periods will give an approximate value of One hundred percent which as well explains the percentage as indicated on the graphs.

\section{RESULTS AND DISCUSSION}

Table 1 presents the results for the Augmented Dickey Fuller unit root test carried out on levels and first differences of maize prices in each of the market over the sampled period. The unit root test on maize prices in all of the markets revealed that prices were non-stationary at levels. However, they became stationary after first differencing i.e. I(1) in sixteen of the selected market and these were the markets on which further analyses were carried on. Lagos urban market was specifically excluded from the analysis as price of maize remained on the same level over the period of data collection.

Table 2 presents a series of Trace tests for cointegration carried out on the investigated markets. The results presented indicate the Unrestricted Co-integration Rank Test using the trace statistics as shown with the corresponding result associated with the number of cointegrating vectors and the decisions to reject (R) or Fail to reject $(\mathrm{F})$ the null hypothesis on the number of cointegrating vectors $(r=0, r \leq 1, \ldots, r \leq 15)$ at a $5 \%$ level of significance.

The result of Trace test revealed the first failure to reject the null hypothesis (denoted by F\#) was observed at thirteen co-integrating vectors. This implies that thirteen long run stationary relations are present in the markets that were investigated. While thirteen long run stationary relations are present in the sixteen markets modelled, it is likely that price in some of the markets will not be a part of the identified thirteen long run relations.

In furtherance to the test of co-integration, test on exclusion was carried out which is meant to exclude each of the markets from the co-integration space and then observe which of the markets exist or do not exist in the co-integration space. Table 3 presents the result of Test on exclusion as carried out. 
Table 1: Summary of Augmented Dickey Fuller (ADF) Tests of non-stationarity carried out on prices (at level) and first differences of maize prices from twenty-four Nigerian markets in year 2015-16

\begin{tabular}{|c|c|c|c|c|c|c|c|c|}
\hline \multirow[t]{2}{*}{$\mathrm{S} / \mathrm{N}$} & \multirow[t]{2}{*}{ Market } & & \multicolumn{3}{|l|}{ Levels } & \multicolumn{3}{|c|}{ First Difference } \\
\hline & & & t-stat & $\mathrm{p}$ value & Lag & t-stat & $\mathrm{p}$ value & Lag \\
\hline 1 & Kwara & Onile aro oloogun(R) & -1.9568 & 0.6103 & 0 & -5.2969 & 0.0004 & 0 \\
\hline 2 & Kwara & $\operatorname{Ago}(\mathrm{U})$ & -0.8964 & 0.9484 & 0 & -6.6345 & 0.0000 & 0 \\
\hline 3 & Abuja & Genge pada (R) & -1.7554 & 0.7112 & 1 & -5.9145 & 0.0001 & 0 \\
\hline 4 & Abuja & Wuse (U) & -1.1278 & 0.9140 & 0 & -5.3699 & 0.0003 & 0 \\
\hline 5 & Kano & Garun Baba (R) & -2.4779 & 0.3374 & 0 & -5.3489 & 0.0003 & 0 \\
\hline 6 & Kano & Dawanou (U) & -2.4166 & 0.3670 & 0 & -4.3965 & 0.0051 & 0 \\
\hline 7 & Kaduna & Kasarami (R) & -0.1548 & 0.9924 & 0 & -6.2705 & 0.0000 & 0 \\
\hline 8 & Kaduna & Kawo (U) & -0.2982 & 0.9887 & 0 & -5.6082 & 0.0001 & 0 \\
\hline 9 & Nasarawa & Odapu ogaji (R) & -3.1327 & 0.1102 & 1 & -5.6274 & 0.0001 & 1 \\
\hline 10 & Nasarawa & Alamis (U) & -2.5782 & 0.2915 & 0 & -4.7252 & 0.0020 & 0 \\
\hline 11 & Imo & Umugunwa (R) & -2.2535 & 0.4508 & 0 & -5.9818 & 0.0000 & 0 \\
\hline 12 & Imo & Eke-Onunwa (U) & -2.0761 & 0.5463 & 0 & -6.0424 & 0.0000 & 0 \\
\hline 13 & Lagos & Garafa $(\mathrm{R})$ & -2.2356 & 0.4603 & 0 & -6.3566 & 0.0000 & 0 \\
\hline 14 & Lagos & Mile $12(\mathrm{U})$ & - & - & - & - & - & - \\
\hline 15 & Ogun & Odeda $(\mathrm{R})$ & -3.5673 & 0.0429 & 0 & -7.2344 & 0.0000 & 0 \\
\hline 16 & Ogun & Kuto (U) & -2.9717 & 0.1500 & 0 & -8.4369 & 0.0000 & 0 \\
\hline 17 & Oyo & Kogijo (R) & -2.2117 & 0.4730 & 0 & -6.7511 & 0.0000 & 0 \\
\hline 18 & Oyo & Bodija (U) & -1.3956 & 0.8505 & 0 & -6.8827 & 0.0000 & 0 \\
\hline 19 & Osun & Ogba-agba (R) & -2.3837 & 0.3833 & 1 & -5.2012 & 0.0005 & 0 \\
\hline 20 & Osun & Igbona (U) & -1.8159 & 0.6824 & 0 & -7.1649 & 0.0000 & 0 \\
\hline 21 & Anambra & Afo Mbaukwu (R) & -2.6309 & 0.2690 & 0 & -8.2681 & 0.0000 & 0 \\
\hline 22 & Anambra & Eke-Awka main(U) & -2.8051 & 0.2022 & 0 & -6.9687 & 0.0000 & 0 \\
\hline 23 & Enugu & Ugwuokpa (R) & -0.8818 & 0.9501 & 0 & -7.9258 & 0.0000 & 0 \\
\hline 24 & Enugu & Ogbete main (U) & -1.2834 & 0.8809 & 0 & -9.0452 & 0.0000 & 0 \\
\hline
\end{tabular}

Source: Data analysis, 2016

Table 2: Test of co-integration among Prices for Maize from Nigerian Markets in 2015-16

\begin{tabular}{llllll}
\hline Hypothesized No. of CE(s) H0: r & Eigen value & Trace Statistic & Critical Value $(0.05)$ & Prob.** & Decision \\
\hline None & 0.999446 & 1416.719 & NA & NA & $\mathrm{R}$ \\
At most 1 & 0.982171 & 1041.815 & NA & NA & R \\
At most 2 & 0.954641 & 840.4685 & NA & NA & R \\
At most 3 & 0.942513 & 685.8113 & NA & NA & R \\
At most 4 & 0.86893 & 543.0011 & 334.9837 & 0 & $\mathrm{R}$ \\
At most 5* & 0.83642 & 441.4 & 285.1425 & 0 & $\mathrm{R}$ \\
At most 6* & 0.771805 & 350.8773 & 239.2354 & 0 & $\mathrm{R}$ \\
At most 7* & 0.699296 & 276.9996 & 197.3709 & 0 & $\mathrm{R}$ \\
At most $8 *$ & 0.61388 & 216.9182 & 159.5297 & 0 & $\mathrm{R}$ \\
At most 9* & 0.577102 & 169.3378 & 125.6154 & 0 & $\mathrm{R}$ \\
At most 10* & 0.545605 & 126.3067 & 95.75366 & 0.0001 & $\mathrm{R}$ \\
At most 11* & 0.487624 & 86.86729 & 69.81889 & 0.0012 & $\mathrm{R}$ \\
At most 12* & 0.395632 & 53.43245 & 47.85613 & 0.0137 & $\mathrm{R}$ \\
At most 13 & 0.287704 & 28.25386 & 29.79707 & 0.0745 & $\mathrm{~F} \#$ \\
At most 14 & 0.201611 & 11.29075 & 15.49471 & 0.1942 & $\mathrm{~F}$ \\
At most 15 & 0.000656 & 0.032806 & 3.841466 & 0.8562 & $\mathrm{~F}$ \\
\hline
\end{tabular}

Note: **MacKinnon-Haug-Michelis (1999) p-values

Source: Data analysis, 2016

Table 3 presents the results in which each of the sixteen markets under investigation was excluded from the co-integration space and the null hypothesis was that the respective market excluded was not in the co-integration space with the test being the distributed Chi Squared with thirteen degree of freedom as zero is being associated with markets in each of the vectors and where $\mathrm{R}$ indicates rejection of the null hypothesis while $\mathrm{F}$ indicates failure to reject the null hypothesis in which case the null hypothesis that the particular market is not within the co-integration space is accepted. The result is presented both for a lag order of one and two. However, the findings were quite similar in both cases.

From Table 3, it can be seen that there was failure to reject the null hypothesis of exclusion on price from both rural and urban markets in Anambra and Ogun States, Ogbete urban Enugu market, Igbona urban market in Osun and Kogijo rural Oyo market. Of all the markets identified as not being in the co-integration space, Kuto market in Ogun State and Afo-mbaukwu market in Anambra State have particularly high exclusion with the p-values of 0.620722 and 0.545312 respectively. It is of particular 
interest to mention observation during data collection which pointed out that these markets had high influx of patronage from Lagos and Port Harcourt cities respectively. Likewise, the regions are not large producers of maize and do not meet their market demands through local production. The prices in these market locations may therefore be an indication of not only occurrences within the localities but rather related trading activities with the mentioned.

VAR Granger Causality otherwise known as Exogeneity Wald test was carried out as an additional test in the empirical analysis to gain more understanding of the dynamic patterns among the markets, and the results is as presented in Table 4. The Exogeneity wald test is meant to establish if a causal relationship exists between each of the market which is in turn made a dependent variable and all other fifteen markets made independent variables. The test was run singly for each of the excluded markets and also for the whole group of fifteen excluded markets against the market made an endogenous variable. The null hypothesis for the VAR granger causality test in this case is that the lagged prices in the fifteen other markets excluded cannot jointly granger cause prices observed in the one market taken as the endogenous or dependent variable.

As shown in the result on Table 4, there is a failure to reject null hypotheses in the cases of both rural and urban markets in Anambra and Ogun States, Garafa rural market in Lagos and Kogijo rural Oyo market. This implies that for these six markets, the null hypothesis that the lagged prices in the fifteen other grouped markets excluded cannot jointly granger-cause prices observed in the each of the market, having taken it as the endogenous or dependent variable was accepted. This is consistent with the results from the Test on exclusion previously carried out which suggested that these markets were not in the same co-integration space as the other markets. For all other cases, the null hypotheses were rejected which implies that prices in each of those markets were actually jointly granger caused by the lagged prices in the fifteen other markets as the case may be.

Table 3: Test on Exclusion of Each of the Sixteen Nigerian Markets from the Co-Integrating Space

\begin{tabular}{llllllll} 
& & Lag 1 & & Lag 2 & & \\
Location & Market & Chi-squared test & p-value & Decision & Chi-squared test & p-value & Decision \\
\hline Anambra (R) & Afo Mbaukwu & 14.71894 & 0.545312 & $\mathrm{~F}$ & 14.06876 & 0.593591 & $\mathrm{~F}$ \\
Kwara (U) & Ago & 34.79363 & 0.004241 & $\mathrm{R}$ & 30.18074 & 0.017087 & $\mathrm{R}$ \\
Anambra (U) & Eke-Awka main & 19.25873 & 0.255475 & $\mathrm{~F}$ & 9.711507 & 0.881254 & $\mathrm{~F}$ \\
Oyo (U) & Bodija & 64.68123 & $8.36 \mathrm{e}-08$ & $\mathrm{R}$ & 39.8374 & 0.000822 & $\mathrm{R}$ \\
Imo (U) & Eke-Onunwa & 27.8198 & 0.033222 & $\mathrm{R}$ & 53.02829 & $7.47 \mathrm{e}-06$ & $\mathrm{R}$ \\
Lagos (R) & Garafa & 26.9967 & 0.041520 & $\mathrm{R}$ & 14.33067 & 0.574094 & $\mathrm{~F}$ \\
Osun (U) & Igbona & 19.64058 & 0.236847 & $\mathrm{~F}$ & 43.36785 & 0.000246 & $\mathrm{R}$ \\
Kaduna (R) & Kasarami & 74.88773 & $1.37 \mathrm{e}-09$ & $\mathrm{R}$ & 32.45511 & 0.008720 & $\mathrm{R}$ \\
Kaduna (U) & Kawo & 74.19816 & $1.82 \mathrm{e}-09$ & $\mathrm{R}$ & 33.26572 & 0.006813 & $\mathrm{R}$ \\
Oyo (R) & Kogijo & 20.92093 & 0.181570 & $\mathrm{~F}$ & 8.962775 & 0.914939 & $\mathrm{~F}$ \\
Ogun (U) & Kuto & 13.70443 & 0.620722 & $\mathrm{~F}$ & 16.78386 & 0.399715 & $\mathrm{~F}$ \\
Ogun (R) & Odeda & 16.75299 & 0.401752 & $\mathrm{~F}$ & 11.61963 & 0.769723 & $\mathrm{~F}$ \\
Nasarawa (R) & Odapu ogaji & 85.80656 & $1.47 \mathrm{e}-11$ & $\mathrm{R}$ & 53.61998 & $5.98 \mathrm{e}-06$ & $\mathrm{R}$ \\
Enugu (U) & Ogbete main & 20.41302 & 0.202192 & $\mathrm{~F}$ & 11.29694 & 0.790797 & $\mathrm{~F}$ \\
Enugu (R) & Ugwuokpa & 47.82385 & $5.06 \mathrm{e}-05$ & $\mathrm{R}$ & 22.6643 & 0.123008 & $\mathrm{~F}$ \\
Imo (R) & Umugunwa & 172.836 & 0.000000 & $\mathrm{R}$ & 189.2457 & 0.000000 & $\mathrm{R}$ \\
\hline
\end{tabular}

Source: Data analysis, 2016

Table 4: VAR Granger Causality /Block Exogeneity Wald Test on the Sixteen Nigerian Markets Modelled for Maize Prices

\begin{tabular}{lllll}
\hline Location & Market & Chi-squared test & p-value & Decision \\
\hline Anambra (R) & Afo Mbaukwu & 37.89108 & 0.1526 & $\mathrm{~F}$ \\
Kwara (U) & Ago & 59.64901 & 0.0010 & $\mathrm{R}$ \\
Anambra (U) & Eke-Awka main & 19.11181 & 0.9376 & $\mathrm{~F}$ \\
Oyo (U) & Bodija & 93.60662 & 0.0000 & $\mathrm{R}$ \\
Imo (U) & Eke-Onunwa & 102.755 & 0.0000 & $\mathrm{R}$ \\
Lagos (R) & Garafa & 35.04237 & 0.2411 & $\mathrm{~F}$ \\
Osun (U) & Igbona & 89.40328 & 0.0000 & $\mathrm{R}$ \\
Kaduna (R) & Kasarami & 56.42893 & 0.0024 & $\mathrm{R}$ \\
Kaduna (U) & Kawo & 45.88211 & 0.0319 & $\mathrm{R}$ \\
Oyo (R) & Kogijo & 15.99802 & 0.9828 & $\mathrm{~F}$ \\
Ogun (U) & Kuto & 38.17905 & 0.1452 & $\mathrm{~F}$ \\
Ogun (R) & Odeda & 43.37316 & 0.0543 & $\mathrm{~F}$ \\
Nasarawa (R) & Odapu ogaji & 98.53122 & 0.0000 & $\mathrm{R}$ \\
Enugu (U) & Ogbete main & 72.12059 & 0.0000 & $\mathrm{R}$ \\
Enugu (R) & Ugwuokpa & 110.2792 & 0.0000 & $\mathrm{R}$ \\
Imo (R) & Umugunwa & 352.2356 & 0.0000 & $\mathrm{R}$
\end{tabular}

Source: Data analysis, 2016 
RAAE / Ajibade et al., 2019: 22 (1) 51-64, doi: 10.15414/raae.2019.22.01.51-64

Table 5. Innovation correlation matrix, $\operatorname{Corr}\left(\varepsilon_{t}\right)$

\begin{tabular}{|c|c|c|c|c|c|c|c|c|c|c|c|c|c|c|c|c|}
\hline & AFO & AGO & AWKA & BOD & EKE & GAF & IGB & KAS & KAW & KOG & KUT & ODE & ODP & OGBE & UGW & UMU \\
\hline AFO & 1.000 & & & & & & & & & & & & & & & \\
\hline AGO & -0.144 & 1.000 & & & & & & & & & & & & & & \\
\hline AWK & 0.071 & -0.089 & 1.000 & & & & & & & & & & & & & \\
\hline BOD & 0.012 & 0.154 & -0.042 & 1.000 & & & & & & & & & & & & \\
\hline EKE & -0.135 & -0.131 & 0.295 & 0.156 & 1.000 & & & & & & & & & & & \\
\hline GAF & 0.284 & 0.284 & -0.266 & 0.277 & 0.129 & 1.000 & & & & & & & & & & \\
\hline IGB & -0.223 & 0.439 & -0.205 & -0.330 & -0.354 & -0.092 & 1.000 & & & & & & & & & \\
\hline KAS & 0.400 & -0.263 & 0.143 & 0.074 & 0.208 & 0.196 & -0.472 & 1.000 & & & & & & & & \\
\hline KAW & 0.095 & -0.388 & 0.073 & 0.072 & 0.056 & 0.068 & -0.188 & 0.589 & 1.000 & & & & & & & \\
\hline KOG & 0.310 & -0.340 & 0.151 & 0.406 & 0.069 & 0.232 & -0.504 & 0.391 & 0.192 & 1.000 & & & & & & \\
\hline KUT & -0.139 & 0.163 & -0.140 & 0.300 & 0.020 & 0.466 & -0.203 & 0.261 & 0.067 & -0.021 & 1.000 & & & & & \\
\hline ODE & -0.290 & 0.447 & -0.529 & 0.124 & -0.491 & 0.169 & 0.138 & -0.273 & -0.293 & -0.157 & 0.269 & 1.000 & & & & \\
\hline ODP & -0.015 & 0.196 & -0.124 & 0.208 & 0.161 & 0.329 & -0.055 & -0.066 & 0.196 & 0.118 & -0.059 & 0.379 & 1.000 & & & \\
\hline OGB & -0.018 & 0.468 & -0.080 & -0.158 & -0.605 & 0.268 & 0.355 & -0.283 & -0.338 & -0.025 & -0.043 & 0.376 & -0.223 & 1.000 & & \\
\hline UGW & 0.361 & -0.242 & 0.044 & -0.350 & -0.066 & 0.151 & -0.097 & 0.186 & 0.166 & 0.243 & -0.260 & -0.391 & -0.134 & 0.172 & 1.000 & \\
\hline UMU & -0.262 & 0.287 & 0.236 & 0.207 & 0.604 & 0.144 & -0.324 & 0.001 & 0.011 & -0.171 & -0.066 & 0.065 & 0.440 & -0.213 & -0.159 & 1.000 \\
\hline
\end{tabular}


The innovation correlation matrix, $\operatorname{Corr}\left(\varepsilon_{t}\right)($ Table 5) indicating the contemporaneous correlation between the error terms, otherwise known as innovations, from the estimated error correction model in each of the sixteen markets modelled.

From the correlation matrix shown in Table 5, the least correlation can be observed between Eke-Onunwa urban market in Imo and Ogbete main market in Enugu. This is particularly interesting considering the close proximity of these two States and the fact that one would expect free flow of market information that should lead to price innovations. On the other hand, focus group discussion and observation during the data collection period indicated the strong influence of Port Harcourt, Rivers State on markets in Owerri municipal and other neighbouring markets. Commodities are generally more expensive in Rivers State which most residents attributed to the presence of a lot of oil production and oil servicing industries coupled with the limited availability of arable land for agricultural production and the low level of involvement in agricultural production. This has consequently placed higher pressure on such neighbouring States as Imo State whereas the state is not exactly a surplus region for crops such as maize but rather still dependent on Northern traders for the bulk of their grains supply. Another pair of market with similarly low correlation is Odeda rural market in Ogun State and EkeAwka main market in urban Anambra State. This may be ascribed in part to the distance of these market pairs and then largely to the fact that Odeda rural market may not be expected to have such influence on other markets considering the low marketing activity going on in the rural market. Interestingly, the innovation correlation between Odeda rural and Kuto urban markets in same Ogun State does not exceed 0.269 which is an indication that both markets are not exceptionally correlated despite being in the same State. Igbonna urban market in Osun State and Kogijo rural market in Oyo State likewise indicates low correlation, with a value of -0.504 , ranking third least correlation among the markets examined. Based on experiential knowledge from the survey period, one may attribute this low correlation to the bad road network and the poor telecommunication facilities which hinder the free flow of market information and even goods among these markets despite the fact that both states are in the same region. On the other hand, traders in Igbona market mostly buy products from farm gates in Osun State before proceeding to patronize Bodija markets and then in certain cases the Northern market. In this case, price information is more likely to be influenced by these points of purchases.

Eke-Onunwa urban and Umugunwa rural markets in Imo State exhibited the largest innovation correlation with a value of 0.604 while the next largest innovation correlation may be found between Kawo and Kasarami markets which are the urban and rural markets sampled in Kaduna State. Kawo and Kaduna are surplus regions for maize exhibiting very low market prices for the commodity. The good road networks and telecommunication services between these markets may be instrumental to the high level of correlation between the pair. However, there exist well-structured assemblage processes which likely ease the flow of market information between the areas.

It is particularly interesting to note that there is a reasonably high level of innovation correlation between Ago urban market in Kwara and Ogbete main market in Enugu State. Based on observation during the survey period, there are large numbers of Eastern traders in Ago market. Although most of these individuals deal in textile products, one may not completely rule out their instrumentality in relaying market and price information to traders in Enugu and other Eastern markets as a way of letting them know the dynamics of the grain markets considering that Kwara is regarded as a gateway to the North. An innovation correlation of 0.466 can be observed between Kuto urban market in Ogun State and Garafa rural market in Lagos State which may be attributed to the proximity of the state and the free flow of information which allows the market pair to sort of influence each other. Umugunwa market in Imo State and Odapu Ogaji market in Nasarawa State indicated an innovation correlation of 0.440 . One may likely attribute this to the fact that Nasarawa State and Imo State are both bound in between by Kogi State, making Nasarawa State the closest Northern State to Imo State where they are likely to access price information and even commodities. Prices of maize in Eke-Awka main market, an urban market in Anambra State showed relatively low innovation correlation with all other maize prices in the sixteen markets under investigation as no innovation correlation observed for this market exceeded 0.295.

PC algorithm was applied to the correlation stated in equation 12 in order to generate the Directed Acyclic graphs to sort out the causal flow on innovation from the Error correction Model on Maize prices from the sixteen markets modelled for maize in this study and the result is as revealed in Figure 1 which presents the Directed Acyclic Graphs indicating the pattern of causal flow on maize price innovations.

It may be gathered from the directed acyclic graphs on maize which is presented in Figure 1 that the prices of maize are discovered from Bodija market in urban Oyo State. Oyo State is not a spectacular producer of maize especially when compared to the production going on in Northern Nigeria. Bodija market is however a major food commodity hub in South-western Nigeria. A phenomenal level of transaction goes on in the market and again the market has the most structured and functional market association of all the sampled market in this study. There are high demands for grains in Bodija market and traders from a considerable number of other states do make purchases from Bodija which results in the high grains demand in the markets. That prices are discovered from Bodija market is an indication of how significant the market is in terms of the commodity pricing in Nigeria. 


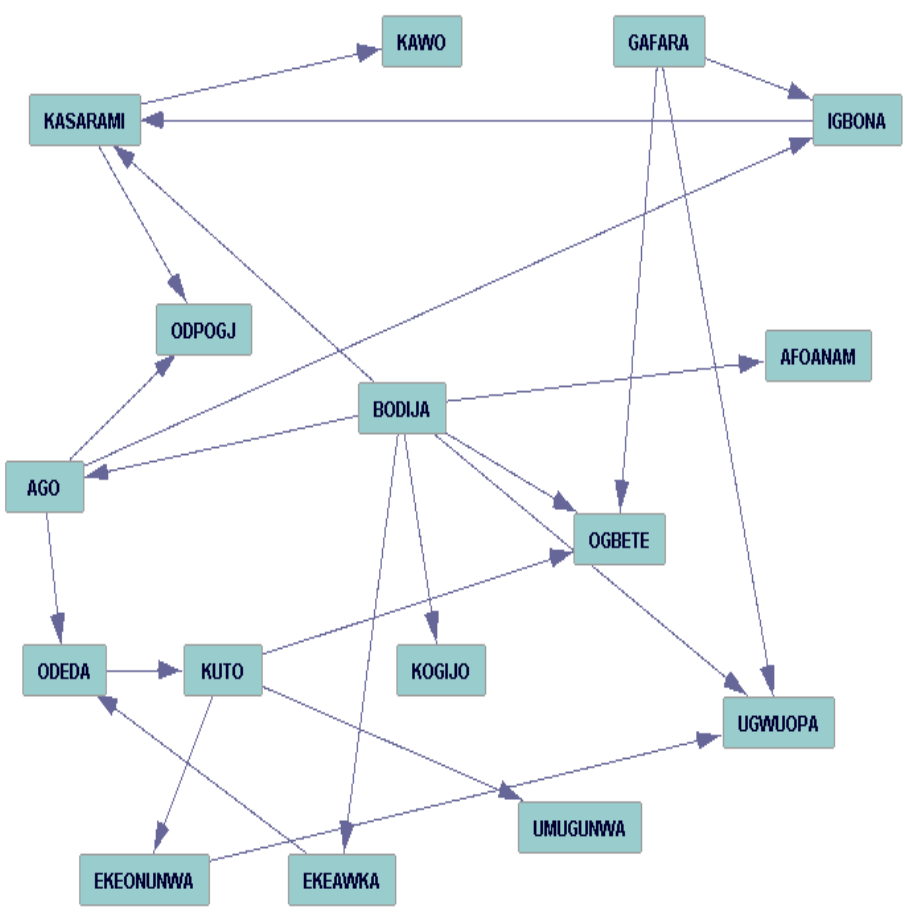

Figure 1: Pattern of causal flow on price innovations among the modelled Nigerian markets for maize Source: Data analysis, 2016

The dynamic relationship existing among the maize markets modelled were observed in the impulse response function result (full result available as supplementary materials available on request to authors). The result revealed each market to be responding to price shocks from itself. This is however untrue in the case of Umungwa rural Imo State market which did not respond in any form to price shocks from itself. Some other markets that did not indicate any profound response to price shocks within self-include Kawo urban Kaduna market, Kuto urban Ogun market and Odapu ogaji market in Nasarawa State.

Odeda rural market in Ogun State could be seen to strongly respond to price shocks from all the other markets with the exception of Umungwa market in Imo State. No market responded to price shocks from Umungwa market in Imo State which implies that the prices of maize in the market does not particular get transmitted to other markets. This might be an indication that the area has an insufficient supply of maize and may be a deficit region in terms of production. Intense changes in market price are seen not to affect Kawo urban Kaduna market, Kogijo rural Oyo market, Kuto urban Ogun market and Eke awka market in Anambra State.

Kawo market in Kaduna is a very big wholesale and international market and of course a surplus region with so much inter-country transactions going on as traders from outside Nigeria patronise the market. It may therefore mean that Kawo market may be responding to price shocks resulting from such trading with other countries more than the observations made on the other fifteen markets being modelled in this work. On the other hand, the scale of production of maize in this region is indeed massive making the region a surplus region which may not readily react to shocks from lower production regions.

The case of Eke awka market being not too responsive to price shocks may be explained by the fact that the area is a deficit region. It is important to mention at this point that white maize is better accepted by consumers in the region than the yellow maize considered in this research work. It may therefore be accounted for that the deficit position in both production and consumption of yellow maize in the region results in the unresponsiveness of the market to price shocks from other markets examined. Kogijo rural Oyo and Kuto urban Ogun market are also low producers of maize and this may account for the nonresponsiveness observed as Kuto depends on Bodija for the bulk of its supply while Kogijo produce in barely enough quantity to supply the rural populace. Likewise, the poor road and communication infrastructure may be shielding information from getting transmitted between Kogijo and other markets modelled in this study. Price shocks from Ogbete main market in Enugu State brought about very minimal responses in all other markets with the exception of itself and Ugwuopa rural Enugu market. This implies that a one-time price shock innovation from Ogbete main market only got responded to by markets sampled within the State which may be as a result of proximity hence ease of information passing among the traders.

The Forecast Error Variance Decomposition was used in interpreting the Vector Autoregressive model in order to be able to explore how responsive the selected markets were to maize price (full result available as supplementary materials available on request to authors). Overall, the 
markets examined for maize price in this study revealed that all the markets, with the exception of Umungwa market in Imo State, are dependent on maize price information generated from within each of the market itself in the contemporaneous time. Some of the markets however still indicated the presence of price externalities at different levels. Kogijo Oyo market, Odeda Ogun market, Ogbete and Ugwuopa Enugu markets indicated that they were dependent on price information generated within them. These markets generated about 49\%, 39\%, $36 \%$ and $38 \%$ respectively and no other market exhibited interference with their price information up to the percentages each generated from within. The only market which indicated a striking position in this maize study in contemporaneous time is Umungwa Imo market which generated about $25 \%$ of its price information whereas Eke awka Imo market generated about $37 \%$ which apparently exceeds what is generated by Umungwa market itself.

One may make the submission that markets are dependent on maize price information generated from within each individual market itself in contemporaneous time which is an indication that instantaneous causal relations seem to be weak in majority of the sampled markets which means that traders may not have enough time to access market information, process the market information or see the need to even seek nor deploy such information in that time period. It may also be a pointer to the dearth of market infrastructures in the markets. This implies that the risk being generated from causal relationship among the markets is quite low in the contemporaneous time.

It could be gleaned that in the short-run the markets still largely retained the sort of behaviour exhibited in the contemporaneous time, however, Umungwa market in Imo got even further higher influences from Kuto market in Abeokuta and Eke onunwa Imo market with either of them generating even more price information than that generated by Umungwa market itself. It may therefore be concluded that fifteen of the sixteen markets modelled in this study were still exogenous at this point since they were independent of price information in other markets.

By variance period 5 which is taken as the intermediate run, changes have occurred in market and up to 43.75 percent of the markets have become endogenous. The seven markets that became endogenous exhibited that other markets in the series supplied to them even more than the price information generated within the market. The top four markets that distinctly stood out in terms of how they generated price information within them include Afo mbawkwu, Bodija, Eke awka and Garafa markets with these markets generating 56.18\%, 56.04\%, 64.0\% and $40.71 \%$ respectively from within itself.

These are particularly interesting points because at this intermediate run, most of the other markets have completely lost potency to generate price information within itself but rather other market gave information exceeding what they generated themselves. Instances are the case of Igbona rural market in Osun State which generated $11.65 \%$ of price information from within itself whereas Ago urban market in Kwara and Garafa rural Lagos market generated $26.5 \%$ and $25.39 \%$ of market information for the market. Also, Bodija market generated
$32.18 \%$ of the price information in Ago market whereas Ago market generated $29.9 \%$ of price information from within itself. Kogijo rural Oyo market at the intermediate run was barely able to generate $13.95 \%$ of its price information whereas Bodija urban Oyo market generated $42.14 \%$ of market information for Kogijo which is more than three hundred percent of what Kogijo generated from within itself. This implies information is freely flowing between the markets at this point. This may be accounted for by proximity considering that they are in the same state. Bodija urban Oyo market was also observed to generate price information of $28.22 \%$ and $35.36 \%$ to Ogbete main market and Ugwuopa markets both in Enugu State whereas those markets generate $13.98 \%$ and $9.10 \%$ of price information from within themselves. At the same intermediate run, Umungwa market generated the least information within itself at a value of $3.04 \%$ whereas other markets exceedingly generated information for it.

One may conclude that in the intermediate run, price information had the opportunity to freely flow among most of the markets. This could mean that information had moved through various mediums which are less speedy but have eventually reached out among the markets. In these markets in the intermediate run therefore, one may conclude more price risk is generated by the total of information coming from all other markets than from within themselves. So far in this study, it appears that the most price disrupting information comes from Bodija urban market in Oyo State

The case of Bodija, Afo mbaukwu and Eke awka markets is still particularly interesting as they appear to have been able to shield themselves from market information from other markets. Bodija may indeed be explained based on the information garnered during survey which indicated the presence of strong market cartels which sort of give them an edge when it comes to product pricing from the Hausa traders while also shielding their market from intrusions. Bodija market appeared to be somewhat difficult to penetrate and would not completely pass for an "open market" even though it seems to be one. The grains marketers have devised various informal strategies that prevent free entry and exit to the grain markets particularly even though these are not clearly defined anywhere.

The impact of new information from Bodija market over the other markets sampled in this study becomes even more prominent in the long run. Bodija can be observed to have more effects on price changes across the regions, the most maize-surplus market in the Northern Nigeria inclusive. No single market generated price information for Bodija market that exceeded the information it generated from within it. However, the only market that generated somewhat large information for Bodija market is Kasarami rural Kaduna market which generated $18.93 \%$ whereas Bodija market generated $37.06 \%$ of price information from within the market itself.

Bodija market likewise generated $30.86 \%$ of the price information within Ago urban Kwara market whereas Ago market generated only $14.67 \%$ of price information from within. In furtherance, Bodija market was observed to generate price information of $39.80 \%, 35.86 \%, 24.76 \%$ and $17.43 \%$ to the prices of maize in Kogijo, Eke awka 
Anambra, Ugwuopa and Kasarami Kaduna markets respectively. This may be put in perspective considering the listed markets generated $11.28 \%, 39 \%, 4.22 \%$ and $26.35 \%$ respectively to its price information from within the market.

Bodija is the largest grain trading markets in Southwestern Nigeria and with most of the commodities traded in coming from Northern Nigeria. The market also has the most structured market association. The market is strategically placed and with very good road networks linking it to several locations in Nigeria cum the presence of good market infrastructure and telephony services. The grain traders in the market are also mostly educated, seasoned and experienced in the business with some of these individuals running generational trade. These may account for why Bodija market has a dominant effect above other markets in directing prices of maize. This finding is consistent with the VAR granger causality test which revealed that the Bodija was highly significant in causing prices in the other markets given the chi-squared value of 98.53 .

The other markets modelled in this study appear to only acquire little information from Umungwa Imo market and Ugwuopa Enugu market even though these markets are indicated to be statistically important by Granger's tests hence these econometric tests exhibited multiple causal relations on prices of maize which may be sort of inconsistent but the findings from the forecast error variance decomposition variance have better reliance.

\section{CONCLUSIONS}

Most of the markets investigated in this study were found to behave in such a manner expected of an open market given that the prices were non-stationary at levels. This implies to a large extent, that interference has been truly removed from the market as should be in this post liberalization era. Furthermore, the integration observed in these spatially segregated markets suggests the extent to which the markets have been liberalized which is revealed as not being fully integrated given that the 16 markets modelled were related in 13 co-integrating relationships whereas 15 would have been expected ideally. Prices of maize are discovered from Bodija markets in South-western Nigeria hence it may be concluded that prices are discovered from the excess demand zones. Majority of the markets were revealed to be responsive to one-time price shock from itself, albeit exhibiting exogeneity in the contemporaneous period but becoming endogenous by the long run (whereby other markets majorly influenced prices) hence indicating that the markets had commendable informational influence on one another. Having established that prices are discovered in the excess demand zone, the study recommended that there should be adequate marketing infrastructures such as good roads and communication networks that improve linkages of these areas with the excess supply zone to facilitate price stabilization. Linkage is key because low production zones have pivotal roles to play in price stabilization, guaranteeing farmers in producing areas get good recompense and of course in improving the welfare of farmers, traders and consumers. The roles of marketing associations cannot be overemphasized hence it should be encouraged by the local government as a way of having traders in groups that gives them access to better price information. Transmission of such price information to the association delegates will assist in giving the information a wider reach. This however needs to be done with genuine intentions to ensure that associations do not get hijacked by a few lobbyists that may end up distorting the market.

\section{REFERENCES}

AJETOMOBI, J. O. (2010). Supply Response, Risk and Institutional Change in Nigerian Agriculture. AERC Research Paper No. 197, Nairobi, Kenya. https://aercafrica.org/wpcontent/uploads/2018/06/RP197.pdf

AWOYEMI, O., AYOTADE, K.A., FAJEMISIN, J., AGO, C.E. and ADENOLA, O. (1986). Meeting the Challenge of cereal self-sufficiency in Nigeria with Special Reference to Rice, Maize and Sorghum. Proceedings of the $4^{\text {th }}$ Joint National Accelerated Food Production Project/ National Agricultural Development Committee Workshop. Adenola O.A, B.A. Okobaroh and I.O. Fatoba (Eds.). Held at the National Cereal Research Institute, Moor Plantation, Ibadan. National Rice/maize Centre (NAFPP). Moor Plantation, Ibadan, pp:13-66.

BALAMI, D. H., OGBORU, I. and TALBA, D. M, (2011). The Cereal Economy in Nigeria and the SubRegional Dimension. A publication of the Social Science Study Group, SSSG Series 1 (29). Makurdi: Benue State University.

BIO, G.S., DAHURI, B. and ROGER, B. (2015). Nigeria's Cereal Economy. Regional Seminar on the Development of Cereal Commodity Chains in West Africa. Thematic paper No. 2 - Summary (Accessed online https://www.google.com/url?sa=tandrct=jandq=andesrc= sandsource $=$ webandcd $=1$ andved $=2$ ahUKEwjKud3jspLe AhUKJ8AKHf3mCvoQFjAAegQICRACandurl=http\%3 A\%2F\%2Fwww.inter-

reseaux.org\%2FIMG\%2Fpdf_Nigeria_s_Cereal_Econom ע_-

Summary No2.pdfandusg=AOvVaw02L1O6lb4EG5x3 857T10N4

BUCHANAN, J.M. and TULLOCK, G. (1965). The Calculus of Consent. Ann Arbor: University of Michigan Press. DOI: $10.3998 / \mathrm{mpub} .7687$

CONWAY, G., WILSON, K., and SHAH, R. (2012). Acute and Chronic Crises. In One Billion Hungry: Can We Feed the World? (pp. 3-20). Cornell University Press. eISBN: 978-0-8014-6608-3 Retrieved from http://www.jstor.org/stable/10.7591/j.cttq43v4.6

DÍAZ-BONILLA E. (2016) Volatile Volatility: Conceptual and Measurement Issues Related to Price Trends and Volatility. In: Kalkuhl M., von Braun J., Torero M. (eds) Food Price Volatility and Its Implications for Food Security and Policy. Springer, Cham https://doi.org/10.1007/978-3-319-28201-5_2

FAN, C.S. and WEI, X. (2005). The Law of One Price: Evidence from the Transitional Economy of China Review of Economics and Statistics 88 (4):682-697 DOI: 
https://doi.org/10.1162/rest.88.4.682

GAUTHIER, D. (1986). Morals by Agreement. New York: Clarendon Press. DOI: $10.2307 / 2185033$

GÓES, C., and MATHESON, T. (2015). Domestic Market Integration and the Law of One Price in Brazil. IMF Working Paper, Western Hemisphere Department. International Monetary Fund (Working Paper No. 15/213). Retrieved $11 \quad$ October 2016. DOI:10.1080/13504851.2016.1184220

IHIMODU, I.I. (2007). Reforms in Agricultural Sector. In: Saliu, H.A., E. Amali and R. Olawepo (Eds). In: Nigeria's Reforms Programme: Issues and Challenges; Ibadan (Ventage Publisher), pp. 236 - 264.

KIRZNER, I.M. (1963). Market Theory and the Price System. D. Van Nostrand Co Inc. Princeton New Jersey Van Nostrand series in Business Administration and Economics. pp 2-3 ISBN-13: 978-0865977600

LAMONT, O.A. and THALER, R.H. (2003). Anomalies: The Law of One Price in Financial Markets. Journal of Economic Perspectives 17 (Fall 2003), pp. 191-202. DOI: $10.1257 / 089533003772034952$

LÜTKEPOHL, H. (2007). New Introduction to Multiple Time Series Analysis. Springer. 63 pp. https://doi.org/10.1111/j.1475-4932.2007.00384.X

MANKIW, N. G. (2011). Principles of Economics (6th ed.). Mason, $\mathrm{OH}$ : South-Western Cengage Learning. Page 686.

MATTHEW, A. and BEN, M. (2016). The Impact of Public Agricultural Expenditure on Agricultural Output in Nigeria (1981-2014). Asian Journal of Agricultural Extension, Economics and Sociology. 11. 1-10. 10.9734/AJAEES/2016/25491.

10.9734/AJAEES/2016/25491

MAZIYA-DIXON, B.I., AKINYELE, O., OGUNTONA, E.B., NOKOE, S., SANUSI, R.A., and HARRIS, E. (2004). Nigeria food consumption and nutrition Survey 2001- 2003 Summary, IITA, Ibadan. ISBN 9781312211 NATIONAL POPULATION COMMISSION (2017). Publication of National Population Commission, Abuja, Nigeria.

OLOMOLA A.S. (2015). Smoothening trends of food prices in Nigeria: Political Economy and Policy Vistas. Paper Presented at the 29th Conference of the International Association of Agricultural Economists, University of Milan, Italy August 8-14.

PEARL, J. (2000). Causality: models, reasoning, and inference. Second edition. Causality. 29. Doi:10.1017/CBO9780511803161. New York: Cambridge University Press

PERSSON, K.G. (2008). Definitions and Explanation of the Law of One Price. eh.net. Economic History Services. Retrieved 6 July 2017. ISBN-13: 978-0521023887

RAVALLION, M. (1986). Testing Market Integration. American Journal of Agricultural Economics (73):102109. DOI: https://doi.org/10.2307/1241654

RONAYNE, D. (2011). Which Impulse Response Function? Warwick Economic Research Papers No. 97, Department of Economics, The University of Warwick, United

Kingdom. http://www2.warwick.ac.uk/fac/soc/economics/staff/phd students/dronayne

ROSSI, E. (2010). Impulse Response Functions.
Econometrics 10, 1-42 Università di Pavia https://www.scribd.com/document/337831897/ImpulseResponse-Functions-pdf

SIMS, C. (1980). Macroeconomics and reality. Econometrica, 48(1980):1- 48. DOI: 10.2307/1912017

SPIRTES, P., GLYMOUR, C. and SCHEINES, R. (2000)

Causation, prediction, and search. Springer-Verlag, New York DOI:10.1007/978-1-4612-2748-9

STIGLER, G.J. and SHERWIN, R.A. (1985). The Extent of the Market. Journal of Law and Economics (27):555585. http://dx.doi.org/10.1086/467101

STOCK, J. H. and WATSON, M.W. (1999). A Comparison of Linear and Nonlinear Univariate Models for Forecasting Macroeconomic Time Series, in Cointegration, Causality, and Forecasting. Festschrift in Honour of Clive W. J. Granger, edited by Engle, R., and White, H., Oxford University Press. http://www.economics.harvard.edu/faculty/stock/files/Gr anger_Festshrift_StockandWatson.pdf

SWANSON, N.R. and GRANGER, C.W.J. (1997). Impulse Response Functions Based on a Causal Approach to Residual Orthogonalization in Vector Autoregressions. Journal of the American Statistical Association Vol. 92, pp. 357-367. DOI: $10.2307 / 2291481$

THIELEMANN, U. (2000). A Brief Theory of the Market - Ethically Focused. International Journal of Social Economics; Vol. 27, Iss: 1, pp.6 - 31. DOI: https://doi.org/10.1108/03068290010306435

TSIMPO, C. and WODON, Q (2008). Rice Prices and Poverty in Liberia. Policy Research Working Paper 4742. World Bank, Washington, DC. DOI: https://doi.org/10.1596/1813-9450-4742.

UNITED NATIONS TREATY COLLECTION (2012), International Covenant on Economic, Social and Cultural Rights, United Nations

VITALE, J. and BESSLER, D.A. (2006). The 2004 Niger Food Crisis: What Role Can Price Discovery Play in Famine Early Warning Systems? Selected Paper prepared for presentation at the American Agricultural Economics Association (AAEA) Annual Meeting, Long Beach, California, July 23-26, 2006 https://www.researchgate.net/deref/http\%3A\%2F\%2Fide as.repec.org\%2Fcgi-

bin $\% 2$ Fhtsearch $\% 3 \mathrm{Fq} \% 3 \mathrm{DThe} \% 2 \mathrm{~B} 2004 \% 2 \mathrm{BNiger} \% 2 \mathrm{~B}$ Food\%2BCrisis $\% 253 \mathrm{~A} \% 2 \mathrm{BWhat} \% 2 \mathrm{BRole} \% 2 \mathrm{BCan} \% 2$ BPrice\%2BDiscovery\%2BPlay\%2Bin\%2BFamine\%2BE arly\%2BWarning\%2BSystems \%253F

WICKSTEED, P.H. (1933). The Common Sense of Political Economy. Vol. 1, London: Routledge. DOI: https://doi.org/10.1215/00182702-36-3-475

WORLD BANK (2015). 'World Development Indicators'. Available at: http://data.worldbank.org/news/release-of-world-

development-indicators-2015 (accessed on 16 October 2016).

WORLD FOOD SUMMIT (1996). Rome Declaration on World Food Security.

ZIVOT, E. and WANG, J. (2006). Vector autoregressive models for multivariate time series. Modeling Financial Time Series with S-Plus, 385-429 DOI: $\underline{10.4236 / j m f .2016 .62027}$ 